\title{
A NEW PLAYING FIELD, GAME AND/OR DIFFERENT RULES? INTO THE FUTURE WITH INDUSTRIAL PSYCHOLOGY AS A DISCIPLINE AND PROFESSION
}

\author{
THEO H VELDSMAN \\ People Effectiveness Consulting Group \\ CS Holdings
}

\begin{abstract}
The aim of the article is to reflect on the future of Industrial Psychology as a discipline and profession. The key consideration is whether Industrial Psychology must reposition itself in the future in terms of a new playing field, game and/or different rules. It is argued that the future playing field of Industrial Psychology will remain essentially the same, although nuance shifts may and/or need to occur. However, the current and emerging content and dynamics within the world of Industrial Psychology will require significant, and even radical, changes in the game and rules within this world. These changes may even necessitate a renaming of Industrial Psychology.
\end{abstract}

\section{OPSOMMING}

Die doel van die artikel is om oor die toekoms van Bedryfsielkunde as dissipline en professie te besin. Die kernoorweging is of Bedryfsielkunde sigself moet herskep vir die toekoms in terme van 'n nuwe speelveld, spel en/of spelreëls. Daar word geredeneer dat die toekomstige speelveld van die Bedryfsielkunde basies dieselfde sal bly, hoewel klemverskuiwing mag en/of behoort plaasvind. Die huidige en ontluikende inhoud van en dinamika in die wêreld van die Bedryfsielkunde sal egter beduidende, en self ingrypende, veranderinge in die spel en spelreëls binne hierdie wêreld teweeg bring.'n Naamverandering vir die Bedryfsielkunde mag selfs oorweeg moet word.

At this juncture in time it appears opportune to reflect on the future of Industrial Psychology as a discipline and profession. Why? With regards to content the discipline and profession have attained a high level of maturity. It has been in existence for more than a 100 years. Maturity implies stepping back and taking stock, especially if the content of the domain seemingly is changing. The context in which Industrial Psychology is embedded in recent years has undergone significant changes, structurally and dynamically. The impact and implications of these changes for Industrial Psychology need to be assessed. "Whereto in the future with Industrial Psychology as discipline and profession?" seems therefore an appropriate and pressing question in search of an answer to consider at this time.

The aim of this article thus is to reflect on the future of Industrial Psychology as discipline and profession. The key consideration is whether Industrial Psychology must reposition itself in the future in terms of a new playing field, game and/or different rules. In answering the question 'whereto in the future with Industrial Psychology?", the author's intention is to provide a window onto the future of the discipline and profession, and not so much as to mirror the present.

It will be argued that the future playing field of Industrial Psychology, the "anatomy" of the discipline and profession, will remain essentially the same although shifts in nuance may and/or need to occur. However, the current and emerging content of, and dynamics within the world of the discipline and profession will necessitate significant, and even radical, changes in the rules and playing of the game. It may be that over time these shifts in game and rules may affect Industrial Psychology's underlying anatomy.

In answering the question of a new playing field, game and/or rules for Industrial Psychology, the following topics are covered:

- mapping the anatomy of the world of Industrial Psychology - its playing field;

- exploring within the topology of this world the question of a new game with different rules for Industrial Psychology;

- suggesting possible responses by Industrial Psychology to the future challenges and opportunities arising from the new game and different rules; and

- naming the world of Industrial Psychology.

Requests for copies should be addressed to: TH Veldsman, CS Holdings, PO Box

786691, Sandton, 2146
For brevity sake the term "Industrial Psychology" is used to cover both the discipline (namely, "Industrial Psychology") and profession (namely, "Industrial Psychologist") throughout the article. Occasionally, and where specifically appropriate, the term "Industrial Psychologist" is used.

\section{MAPPING THE WORLD OF INDUSTRIAL PSYCHOLOGY}

The anatomy of Industrial Psychology's world can be mapped as follows:

- the dimensions and anchors of the world of Industrial Psychology;

- the roles and action modes within this world; and

- the core identity of the discipline and profession.

Each aspect is discussed in turn.

The dimensions of Industrial Psychology's world Industrial Psychology lives in both a Theoretical (or Reflective) World and a Practical (or Doing) World. Both worlds consist of Outcomes and Means. The combination of these four dimensions delineate four interdependent, interactive engagement domains for Industrial Psychology, namely Understanding, Solutions, Methodology and Technology.

- Understanding pertains to " insight into";

- Solutions to "the realization and/or resolution of opportunities, issues and problems";

- Methodology to " conceptual approaches, processes and tools used to arrive at Understanding" ; and

- Technology to "action orientated approaches, processes and tools to build, design and implement Solutions".

Methodology and Technology thus are enablers, or the means to achieve Insight and Solutions. Figure 1 illustrates the four engagement domains.

FIGURE 1 THE ENGAGEMENT DOMAINS OF INDUSTRIAL PSYCHOLOGY'S WORLD

As depicted in Figure 1 the four engagement domains form an 


$$
\begin{aligned}
& \text { THEORETICAL } \\
& \text { WORLD } \\
& \text { (Reflection) }
\end{aligned}
$$

PRACTICAL

WORLD

(Doing)

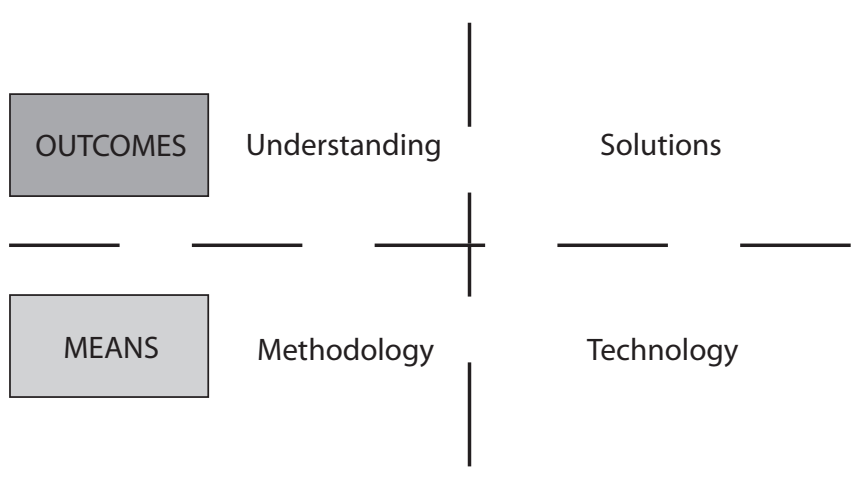

inseparable whole which encompasses the Theoretical and Practical Worlds with their respective Outcomes and Means. Hence the dotted lines in Figure 1. An Industrial Psychologist functions dynamically across these domains. The focus need not constantly be on one domain. Shifts may occur between being a contributor to one domain (e.g. building Understanding) or being a trusting "consumer" in another (e.g., using a certain Technology to arrive at a Solution).

The Anchors of Industrial Psychology's World

If theory and practice, as well as outcomes and means, form the anatomical dimensions of Industrial Psychology, what are the anchors of this world?

\section{Four anchors can be distinguished:}

Anchor 1: The Reality Addressed

This anchor sits on the Outcomes-side between the Theoretical and Practical Worlds of Industrial Psychology (see Figure 1). It pertains to the reality addressed by Industrial Psychology, namely the world of work. Within the world of work the focus of Industrial Psychology is on the nature; here-and-now dynamics; and change over time (whether spontaneous and/or induced through interventions) with respect to individuals, teams, organizations and communities/ societies, as well as the interactions between these entities.

An important suggested future extension to the content of this anchor of Industrial Psychology is the inclusion of communities/ societies from a world of work perspective. Issues to be considered in this case are, for example, work ideologies and systems, work legislation, policies and ethics. These issues form the macro work setting and have an important impact on the micro work setting.

Significant and major socio-political and legislative transformations are in process, and will continue to occur. It creates the macro setting which cannot be divorced from Industrial Psychology itself. Increasingly in the future Industrial Psychology therefore will need to become involved in the design, implementation and assessment of macro work settings. In principle Anchor 1 contentwise applies equally to the Industrial Psychologist and to the People Management (or Human Resources) Practitioner: both are engaged with the world of work.

\section{Anchor 2: Vantage Point}

Similar to Anchor 1 this anchor is located between the Theoretical and Practical Worlds of Industrial Psychology, but on the Means-side (see Figure 1). Anchor 2 encompasses the basic point of departure that is adopted in engaging with the reality addressed, Anchor 1.

It is proposed that Industrial Psychology's unique vantage point on the world of work (Anchor 1) is the psycho-social contract. The psycho-social contract encompasses the set(s) of mutual expectations regarding contributions by and requirements from the actors making up a specific work setting, for example the stakeholders of a work organisation. It is proposed that Industrial Psychology seeks to understand and bring about sound psycho-social contracts typified by: legitimacy ("should do"); competence ("can do'); energy ("will do"); autonomy ("may do"); and rewards/recognition ("want to do").

The mutual expectations making up the psycho-social contract provides answers to six fundamental "world of work" questions:

- identify conception/formation and yields: who am l/are we, what do I/we do, and what do I/we want to achieve with what benefits?

- resource attraction/deployment: what do I/we need to get the work done, and where do $\mathrm{l} /$ we get it from?

- pattern establishment/maintenance: how do I/we organize ourselves?

- interaction dynamics: how do I/we relate to and interact with others?

- value creation: Who defines value? How is it defined? How do I/we deliver value?

- governance: how do I/we distribute authority and responsibility, and with what autonomy?

In contrast to the psycho-social contract as vantage point of Industrial Psychology, it is suggested that the employment contract is the vantage point of the People Management Practitioner: the formal conditions and processes of employment with its associated rights, privileges and obligations. In process and type the psycho-social contract, however, underpins and shapes the employment contract. The latter is the tip of the iceberg above the water, with the former being the portion of the iceberg under the water. For example: recruitment, selection, placement and termination (elements of the employment contract) presuppose the processes of mutual attraction, choice and attachment (elements of the psycho-social contract) which occur within the context of a certain type of contract, for example one of instrumentality, namely a reward-effort exchange.

Unfortunately in trying to prove its practical utility, Industrial Psychology very frequently substitutes its true vantage point, i.e. the psycho-social contract, for that of the employment contract. In this way it devalues its true and unique contribution around Understanding and Solutions based on a psycho-social contractual perspective. The sooner a clearer distinction is drawn during academic and professional training between the Industrial Psychology and People Management the better.

Anchor 3: Theoretical Knowledge

This anchor is embedded in the Theoretical World, between Outcomes and Means (see Figure 1). Anchor 3 entails the "What's", "Why's" and "Whereto's" of the world of work from a psycho-social contractual perspective. Answers to questions such as the following, for example, are sought:

- Competencies: What are the structures and dynamics of competencies? How do they develop over time?

- Relationship formation and development: What attracts individuals to organizations? What influences their choice in this regard? What keeps them attached to their chosen organizations?

- Team dynamics: What factors influence effective team functioning?

\section{Anchor 4: Practical Wisdom}

This anchor also sits between Outcomes and Means, but in the Practical World (see Figure 1). Practical Wisdom is knowing when to do what with whom. Practical Wisdom thus refers to the "How". For example: designing and implementing a performance management process for an organization based on sound motivation theory and principles; building a change navigation intervention taking account of the personal transition change cycle in order to sustain energy levels within an organization and engender commitment to a future desired state.

The four anchors described above are dynamically interconnected. The movement between them is continuous and iterative. Two primary axies of movement can be discerned:

between Anchor 1: The Reality Addressed and Anchor 2: Vantage Point. This movement axis pertains essentially to knowledge/ 
wisdom generation, encoding and dissemination. The process linking these two anchors run from: Conceive an idea (Anchor 1: The reality addressed) through Formulate, Test and Enact, to Reflect and/or Disseminate (Anchor 2: Vantage point).

As one moves iteratively along this axis, the relative mix changes between "Getting there" (that is, seeking and finding Theoretical Knowledge and/or Practical Wisdom) and "Being there" (that is, having the Theoretical Knowledge and/or Practical Wisdom at one's disposal to use in the form of Understanding and/or Solutions). Figure 2 depicts this discussion. The figure shows the knowledge/wisdom generation, encoding and dissemination processes along the dynamic axis between Anchors 1 and 2, and how the relative weighting changes between " Getting there" and "Being there" as one moves along this axis.

FIGURE 2 DYNAMIC MOVEMENT BETWEEN THE ANCHORS OF REALITY ADDRESSED AND VANTAGE POINT

It is proposed that the Industrial Psychologist and People Management Practitioner use a similar iterative, dynamic movement along the Anchor 1-Anchor 2 axis. They partake in the same processes of knowledge/wisdom generation, encoding and dissemination. This of course happens from their different vantage points, i.e. the psycho-social and employment contracts respectively.

between Anchor 3: Theoretical Knowledge and Anchor 4: Practical Wisdom. This axis encompasses movement, again iteratively and dynamically, between sequentially arranged Theoretical and Practical Wisdom knowledge objects. These are

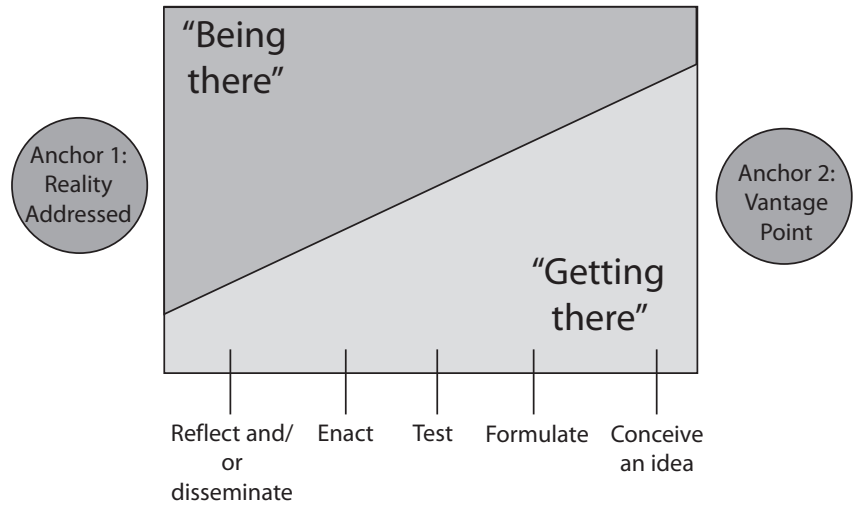

paradigms; theories and concepts; principles and models; policies and standards; systems and practices; and concrete daily actions. A former object forms the basis for a latter object. E.g. paradigms precede theories and concepts. Inversely, a latter object, e.g. systems and practices, can trigger the development or change in a former object, in this case: principles and models. In moving from paradigms through to concrete daily actions the relative weighting in the qualitative nature of objects changes from predominantly the "What's", 'Why's" and "Whereto's" of the Theoretical World to the "How's" of the Practical World, and vice versa. Figure 3 illustrates this iterative, dynamic movement along the Theoretical/Practical Wisdom knowledge object axis.

Figure 3: Dynamic movement betWeen the ANCHORS Of theoretical KNOWLEDGE AND PRACTICAL WISDOM

The Industrial Psychologist's primary interest is in producing the Theoretical knowledge objects of paradigms, theories, concepts, principles and models, that populate the Theoretical World and express Understanding from a psycho-social contract perspective. An example is the principles and model related to the design of organizations in a hyperturbulent setting. The Theoretical knowledge objects of Understanding inform the production of the Practical Wisdom knowledge objects of policies and standards; systems and practices; and concrete daily actions. In this case, the appropriate structures, roles, responsibilities and authority within an organization, based on the design principles and model appropriate to a hyperturbulent setting.

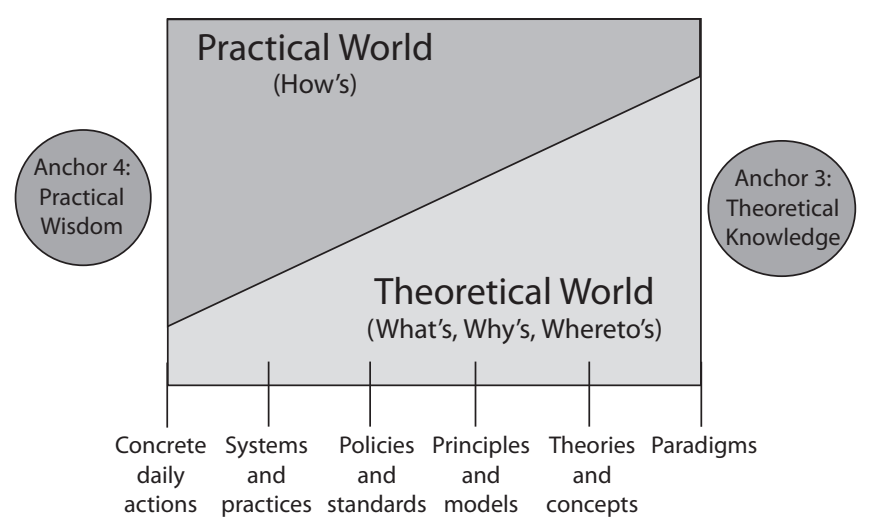

The People Management Practitioner predominantly focuses on the production of the Practical Wisdom knowledge objects of policies and standards; systems and practices; and concrete daily actions which compose the Practical World and provide Solutions from an Employment Contract perspective. In the process he/she uses the Theoretical knowledge objects delivered by the Industrial Psychologist. These Practical Wisdom knowledge objects as Solutions in turn confirm, enrich, extend and/or change the Theoretical knowledge objects of Industrial Psychology. The understanding of organizational design serves as an example.

This dynamic, iterative movement along the knowledge objects axis is the ideal. Currently the knowledge objects closer to Practical Wisdom (Anchor 4), e.g. daily concrete actions, systems and practices, are generated with little reference very often to the knowledge objects closer to Theoretical Knowledge (Anchor 3), and vice versa. A seamless, rapid two-directional movement along the knowledge objects axis is a dire need for Industrial Psychology as it moves into a future. This is necessitated by the rapid production, use and discarding of knowledge objects, especially around Practical Wisdom. It is estimated that $65 \%$ of new knowledge at present is generated outside formal academic institutions.

The Roles and Action Modes within the Industrial

Psychology's World

Given the engagement domains and anchors of the Industrial Psychology's world, the following four roles can be distinguished for the Industrial Psychologist:

- Conceptualiser: extend, enhance and change Theoretical Knowledge (Anchor 3) through Understanding within the Theoretical World. This means the generation of the Theoretical knowledge objects of the world of work. The knowledge objects so produced now become available for consumption in the Practical World. The vantage point (Anchor 2) in the case of Industrial Psychology is, as has been stated, the psycho-social contract.

- Methodologist: generate the means (for example, research approaches and designs, data gathering methods, as well as statistical analysis tools) by which Understanding can be established within the Theoretical world, and be tested in the Practical World.

- Consultant: build, implement and assess Solutions to challenges existing/emerging within the Practical World (that is, Practical Wisdom knowledge objects related to the world of work). This enriches or replaces Practical Wisdom (Anchor 4). In this process the practical value of Theoretical knowledge objects is tested. Gaps in the existing Theoretical knowledge also may be demonstrated. Again the vantage point for Industrial Psychology is the psycho-social contract.

- Technologist: supply the wherewithal (e.g. action approaches, methodologies and tools) by which Solutions can be designed for, implemented into, and institutionalised in the world of work. 
With respect to each of the above roles, four generic action modes can be distinguished for the Industrial Psychologist:

- Diagnostician: what is happening/has happened? For example, what are the current people dynamics in this organisation? The focus is very much on current state assessment.

- Advocate or Champion: What should/must happen? How should the people dynamics look? The emphasis is on the future desired state.

- Capacity Builder: How to enable what is/should/must happen? What capabilities must be built and/or deployed into organisations to equip actors within the organisation to change the dynamics?

- Interventionist: how to change what is/should be happening? The focus is on choosing and rolling out interventions to close the gap between the current and future desired states.

The above examples given for each action mode have assumed a Consultant role. If another role is adopted, e.g. Conceptualiser, the action modes will look different within the context of that role. The world of Industrial Psychology is at present characterized by a crippling schizophrenic split which is detrimental to its growth and potential contribution. Currently most attention is given to the Conceptualiser and Methodologist roles. The Consultant and Technologist roles do not formally receive attention during academic and professional training, although by far the greatest majority of Industrial Psychologists adopt these roles as career choices. Therefore Industrial Psychologists are not formally trained for what they eventually will do.

The attention given to all four action modes is only within the context of the Conceptualiser and Methodologist roles. Without any doubt, in the future all four roles with their commensurate action modes must receive equal attention if Industrial Psychology wishes to become a vibrant, well rounded discipline and profession. The schizophrenic divide must be eradicated. A coherent world of engagement domains, anchors, roles and action modes must be presented during education and training.

The Core Identity of Industrial Psychology as Discipline and Practice

Identity pertains to what and who an entity or person is in its/his/her essence. It is proposed that the core identity of Industrial Psychology can be profiled as:

- a field of enquiry, a discipline, and a domain of practice, a profession;

- focusing on the people world of work from a psycho-social perspective;

- by striving for an understanding and enhancement of this world;

- through the generation and utilisation of theoretical/wisdom knowledge objects with respect to the people world of work.

The building blocks of Industrial Psychology as a discipline and profession, are:

- the philosophy of Industrial Psychology: its ultimate and fundamental presuppositions about the processes of Reflection and Doing; the status (e.g. the reliability, validity) of the outcomes of such processes, that is its Theoretical Knowledge and Practical Wisdom; and the basic nature of its Vantage Point and Reality Addressed.

- Industrial Psychology's history: its past, present and expected future unfolding, not only in terms of historical content but also with respect to its historical context and dynamics.

- the systematised body of knowledge/wisdom of Industrial Psychology in its verified, validated ("as is") and reflective-critical ("should be") forms expressed in terms of Theoretical/Wisdom knowledge objects (e.g. theories, models, policies, systems, practices) as well as the processes (the means) to arrive at such objects, that is its methodologies and technologies.

- the roles, action modes, and competencies of Industrial Psychology addressing the profile, dynamics and outcomes of such roles and action modes, and the competencies regarding them.

- Industrial Psychology's communities of practice with their respective ethical codes of conduct, focusing on the infrastructural features and dynamics of Industrial Psychology, e.g. its research, professional (or organized) and client communities, and what is desirable and acceptable conduct within such communities.

Up to the present the major emphasis in Industrial Psychology has been on its systematised body of knowledge/wisdom as expressed in and organised around its sub-disciplines. Its philosophy; history; roles; action modes and competencies; as well as its communities of practice have received little, if any attention. If Industrial Psychology wishes to become a "full range" discipline and profession, 'these other building blocks will have to receive explicit and equal attention in the future. If the renewal of Industrial Psychology as discipline and profession is to occur the following needs to be done:

- the relevancy and adequacy of its philosophical underpinnings must be understood and debated;

- future trends in the world of work from a historical perspective need to be uncovered:

- the full range of roles, action modes and competencies must be addressed; and

- building insight into the infra-structure and dynamics of communities of practices which will enable the Industrial Psychologist to enhance its effectiveness and efficiency.

Figure 4 provides an overall graphic summary of the anatomy of Industrial Psychology's world covering its engagement domains, anchors, roles and action modes.

\section{FIGURE 4: ANATOMY OF INDUSTRIAL PSYCHOLOGY'S WORLD}

It is suggested that the anatomy of the playing field of Industrial Psychology, except perhaps for nuance shifts, will remain essentially the same for Industrial Psychology in the foreseeable future. It is more a case of operating in the future across the whole world in which the Industrial Psychologist functions, giving equal attention to all of its engagement domains, anchors, roles with their action modes, and its core identity, rather than transforming this world in any fundamental way. This brings one to the future game and rules for Industrial Psychology.

\section{EXPLORING THE NEW GAME WITH ITS DIFFERENT RULES FOR INDUSTRIAL PSYCHOLOGY}

It is proposed that the change drivers for the suggested future shifts in the game and rules for the playing field of Industrial Psychology, as demarcated by its anatomy, can be grouped into the following change driver reference points:

- game reference points:

- a changing world of work;

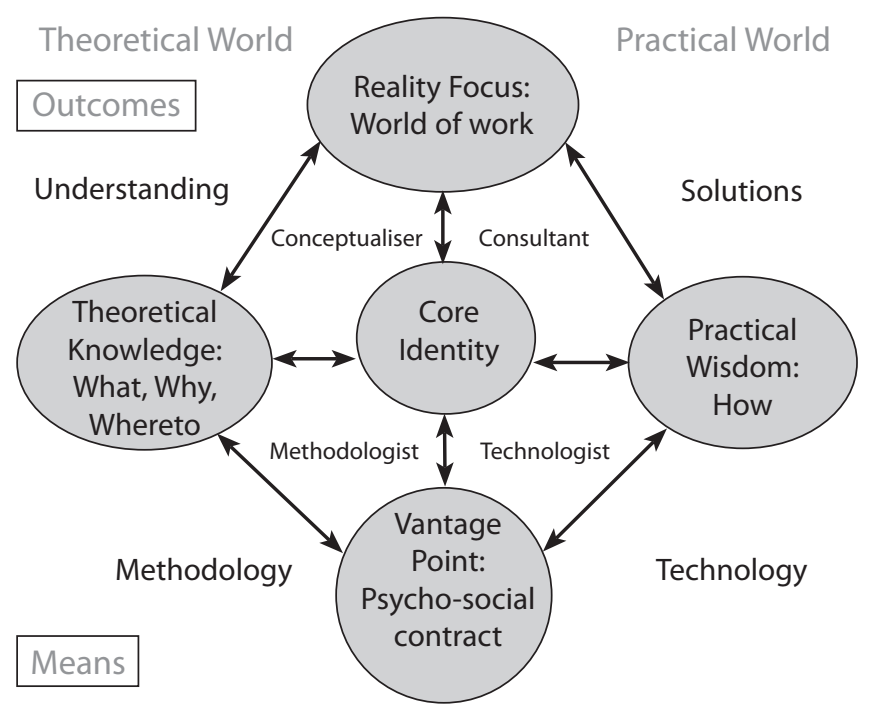

- a transforming and transformed client community;

- a redefining practice framework for Industrial Psychologists; 
and

- distributed, ongoing learning by Industrial Psychologists; and

- a rule reference point:

- a reframed and reframing engagement mode within her/his world for Industrial Psychologists.

Figure 5 depicts the shifts and trends with respect to the game reference points. In terms of this figure significant and radical changes are occurring with respect to the game Industrial Psychology has to play.

According to Figure 5 the new game within the world of Industrial Psychology can be depicted as follows:

- a changing world of work reflected in a reframed work setting complemented by richer skills/experience repertoires and densities; different people profiles and expected conduct.

- a transforming and transformed client community with shifts in client profile and conduct; product/service offerings; and delivery parameters and processes.

- a redefining practice framework with an increasing distinction between the discipline and profession of Industrial Psychology; more explicit formalized professionalisation processes and structures; and different practice infrastructures.

- distributed ongoing learning which embraces changes in roles, location, content and processes around learning.

\section{A CHANGING WORLD OF WORK}

- Rigid, command-and-control, information starved, functionally based work settings driven by objectives, standards, plans $\rightarrow$ Responsive, empowering, information rich, distributed value networks driven by vision, values and interventions

- Limited skills/experience repertoires at low levels of complexity with low densities $\rightarrow$ Wide skills/experience repertoires at high levels of complexity with high densities

- Submissive, accepting, passive, reactive employees with external locus of control $\rightarrow$ Assertive, challenging, active, forward looking contributors with internal locus of control

- Individualistic, risk avoiding, one best way, directed conduct aimed at doing things right $\rightarrow$ Teaming, risk seeking, innovative, flexible, self- initiated conduct aimed at doing the right things
What are the implications of these changes for Industrial Psychology's world? Though the topology of this world is not expected to change in its essence, the following shifts can be expected:

- the need to understand and find solutions to the new psychosocial contract because of the changing world of work;

- accelerated knowledge/wisdom generation, encoding and dissemination processes (see Figure 2) as Theoretical/Wisdom knowledge objects become much more rapidly obsolescent;

- genuinely working in a seamless and sharing fashion across the engagement domains of Industrial Psychology (see Figure 1);

- placing much more emphasis on the neglected building blocks of Industrial Psychology namely its philosophy, history, roles/action modes/competencies, and communities of practice. The shifts in the underlying structures and normative foundations of Industrial Psychology's world emphasize this change.

Against the backdrop of the changing game within the world of the Industrial Psychologist (see Figure 5), Table 1 provides an overview of the changing rules within that world as expressed in a reframed and reframing engagement mode.

According to Table 1 the reframed and reframing engagement mode, the different rules, for the new game Industrial Psychology has to play in the future implies the following:

\section{A TRANSFORMING AND TRANSFORMED CLIENT OMMUNITY}

- Homogenous client base $\rightarrow$ Diverse client base

- Passive, receptive clients with low expectations $\rightarrow$ Assertive, prescriptive clients with high expectations

- Static, simple relationship $\rightarrow$ Dynamic, complex relationship

- Wide range service offering from a single source $\rightarrow$ Niched service offering sourced from a network

- Clear distinction between products and services $\rightarrow$ Blurring products/servics distinctions

- Tangible offerings $\rightarrow$ Intangible offerings

- Dumb offerings (learning made by provider) $\rightarrow$ Smart offerings (client learns)

- Price determined by service provider $\rightarrow$ Client prices offering through auctioning

- Set delivery times $\rightarrow$ Ever decreasing delivery times

- Single delivery mode, location, time $\rightarrow$ Anything, anytime, anyplace, anyhow

A REFRAMED AND REFRAMING

ENGAGEMENT MODE

(The rules of the game)

- Blurred academic and professional education $\rightarrow$ Clear differentiation between discipline and practice

- Accidental professional socialisation $\rightarrow$ Deliberate professional socialisation

- Single tiered profession $\rightarrow$ Multi-tiered profession

- National registration $\rightarrow$ Globally recognised registration

- Life long, fixed competency set/registration category $\rightarrow$ Ongoing re-titlement as needs and competencies to satisfy needs, shifts

- Voluntary, ad hoc education/training $\rightarrow$ Compulsory, ongoing education/ training

- Physical, local practice location $\rightarrow$ Virtual, global practice

- Uni-disciplinary practice $\rightarrow$ Multi-disciplinary practice

\section{A REDEFINING PRACTICE FRAMEWORK}

- Teacher $\rightarrow$ Learning mediators, mentors and coaches

- Physical, localised, teaching location $\rightarrow$ Virtual, globalised, distributed learning network/communities

- Clear boundaries between teaching and practice $\rightarrow$ Vague, shifting boundaries between teaching/practice

- One way transfer of teaching $\rightarrow$ Multi-directional transfer of learning

- Once-off teaching through single teaching mode $\rightarrow$ Ongoing learning through multiple learning modes

- Teaching knowledge $\rightarrow$ Learning knowledge and wisdom

- Presented teaching content from one single course $\rightarrow$ Self constructed, just-intime learning content from multiple sources

- Stable body of knowledge $\rightarrow$ Ever increasing half life of knowledge and wisdom

\section{DISTRIBUTED, ONGOING LEARNING}


- a wider range of stakeholders (the "who");

- a broadened practice location (the "where");

- more diverse contributions (the "what");

- different delivery characteristics (the "how"); and

- a shift in the ultimate desired outcome (the "whereto").

From the above discussion, it should be clear that Industrial Psychology will be playing a new game with different rules in the future within its world. This raises questions regarding possible responses by Industrial Psychology to the future challenges and opportunities. What are the implications of the new game and different rules? This question is next addressed.

\section{POSSIBLE RESPONSES TO THE FUTURE CHALLENGES AND OPPORTUNITIES FACED BY INDUSTRIAL PSYCHOLOGY WITHIN ITS WORLD}

Figure 6 depicts possible responses by Industrial Psychology to the new game with its different rules. The responses are grouped in terms of the interfaces (the "white spaces") between the four game change driver reference points: a changing world of work; a transforming and transformed client community; a redefining practice framework; and distributed, ongoing learning.

According to Figure 6 the new game with its different rules will necessitate that Industrial Psychologists and Industrial Psychology face different future challenges and opportunities. Different responses will be required. All in all, the world of Industrial Psychology will become more fluid, dynamic, complex, ambiguous, interdependent, and without distinct boundaries. The substantive responses to the future challenges and opportunities depicted in Figure 6 will require qualitatively different responses. More of the same will no longer be suffice.

FigURE 6: PosSible RESPONSES BY INDUSTRIAL PSYCHOLOGY TO FUTURE CHALLENGES AND OPPORTUNITIES IN ITS WORLD

TABLE 1: CHANGING RULES WITHIN THE WORLD OF THE INDUSTRIAL PSYCHOLOGISTS: A REFRAMING AND REFRAMING ENGAGEMENT MODE

\section{TRADITIONAL ENGAGEMENT MODEEMERGING ENGAGEMENT MODE}

WHO?

Management as single stakeholder

WHERE?

Large organisations in staff departments at technical operational level

WHAT?

Stand alone practices/systems/functional HR areas

HOW?

- Technical expert in an advisory role or a Line Functionary

- Intra-disciplinary and Intra-organisational

- Once-off, ad hoc data-gathering

- Imported knowledge and technological base

- Scientific method mode

- Elementistic, piecemeal, linear thinking and doing

- Improvements within predefined frameworks

- Value-free techniques and procedures

- Implicit white, male, middle class values •

- Reactive, passive, non- accountable

- Exclusiveness in terms of qualifications and skills

- Little regard for bottom line impact
WHO?

Multiple stakeholders, i.e. anybody and everybody, anywhere

WHERE?

Everywhere: large organisations/unions in formal sector; non-economic organisations/movements; political decision makers; communities; society.

WHAT?

- Proactive visions: Visionaries and Missionaries

- Common value systems and unifying symbols: Value Brokers and Boundary Spanners

- Organisational transformation/revitalisation: Change Agents and Learning Brokers

- Integrated people strategies, policies, objectives and systems: Conceptualisers and Strategists

- Mass remedial approaches to deal with causes and symptoms of change stresses: Mediators and Remediators

\section{HOW?}

- Transformational leadership working directly alongside client/customer: Visions, values and processes

- Multi- and interdisciplinary, as well as inter-organisational

- Continuous environmental scanning and rapid information gathering, diagnosis and feedback

- Indigenous knowledge networking and information exchanges

- Action research mode

- Holistic, integrated, lateral thinking and doing

- Redefinition of traditionally accepted frameworks

- Value driven approaches and procedures

Bracketing of personal value systems and multiple value system involvement

- Proactive, assertive, accountable

- Popularisation of skill and knowledge to cope with growing needs

- Multiple bottom line consciousness and impact assessment, for example financial, social and environmental
WHERETO?

Short to medium term technical - operational benefits

\section{WHERETO?}

Sustainable, thriving work communities with productive and satisfied people in a flourishing society 


\section{NAMING THE WORLD OF INDUSTRIAL PSYCHOLOGY}

Industrial Psychology has moved beyond the turn of the previous century when the Industrial Society was at its zenith. The Information, and presently the Knowledge Society rules with a new game which has different rules. Industrial Psychology therefore has to make its contribution within this new setting. This leads to questioning the appropriateness of the names "Industrial Psychology" and "Industrial Psychologist", stemming from the Industrial Society's hey day. It is contented that a name change must seriously be considered.

It is suggested that regarding the discipline the following names are worth considering:

- the Psychology of Work;

- Work Psychology; or

- Workology (i.e., the science of work).

With respect to the profession of Industrial Psychology possible generic names at the Psychologist level are:

- Work Psychologist;

- Consulting Psychologist; or
Of course, the question, has to asked whether its is a good time for Industrial Psychology to undergo a name change at this juncture in time. The existing name, or its extension Industrial and Organisational Psychology, has now become (atlong last!) knownand institutionalised in academic and public circles. The author's personal preference is that one must seriously consider a name change, with his preferred choices being: Work Psychology; Work Psychologist; and Work Counselor (in Afrikaans: Arbeidsielkunde; Arbeidsielkundige; Werksberader).

\section{CONCLUSION}

The aim of the article was to reflect on the future of Industrial Psychology as discipline and profession: does the future imply a new playing field, game and/or different rules?

It was concluded that the future playing field of Industrial Psychology the anatomy of the discipline and profession, will remain essentially the same in terms of engagement domains (i.e. Understanding, Solutions, Methodology and Technology). It is also true for the anchors (i.e. the Reality Addressed, Vantage Point adopted, Theoretical

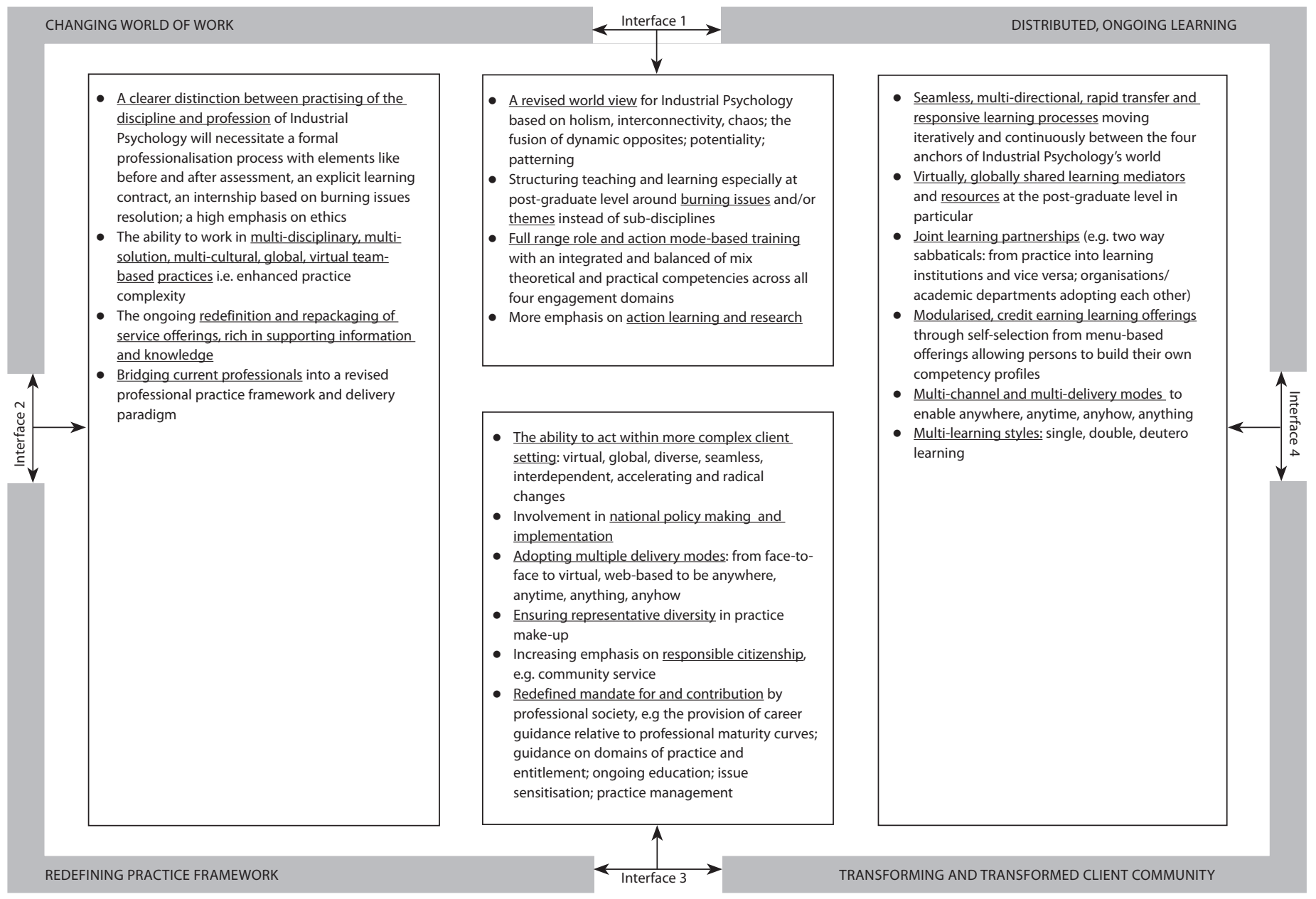

- Organisational Psychologist.

Each of these names could be qualified in brackets after the name by the domain in which the Psychologist has knowledge, expertise and experience, e.g.

- Performance Enhancement;

- Assessment and Measurement; or

- Change navigation.

At the Registered Counselor level, possible names could be:

- Work Counselor;

- Employment Relations Counselor; or

- Organisational Counselor.
Knowledge, Practical Wisdom); roles (i.e. Conceptualiser, Methodologist, Consultant, Technologist); action modes (Diagnostician, Advocate, Capacity Builder, Interventionist); and core identity.

Shifts in nuance, however, have to occur in Industrial Psychology's world. Communities/society from a world of work perspective must receive more attention. The roles of Consultant and Technologist must be formally included in academic and professional training. The building blocks of philosophy, history, roles, action modes and competencies, as well as communities of practice, must also be covered more explicitly.

A new game with different rules for Industrial Psychology however 
has been, and is emerging within the world of Industrial Psychologist. This finds its expression in a changing world of work; a transforming and transformed client community; a redefining practice framework; and distributed, ongoing learning. The different rules are manifested in a reframed and reframing mode of engagement with his/her world for Industrial Psychologists. Arising from this new game with different rules, possible responses to the future challenges and opportunities were discussed.

Finally, the naming of the world of Industrial Psychology was addressed. It was argued that revised names must be considered for the discipline and profession within a Knowledge Society. The author's preferred choices are: Work Psychology; Work Psychologist; and Work Counselor.

Without any doubt Work Psychology as discipline and profession has a bright future, but only if Work Psychology faces up to a new game with different rules in its world. This demands the finding of new answers to the "What's", "Why's", Whereto's and "How's" of the discipline and profession.

\section{REFERENCES}

Brewster, C. , Dawling, P. , Grobler, P., Holland, P. \& Wärnich, S. (2000) Contemporary issues in human resource management. Oxford: Oxford University Press.

Cappeli, P. (1999) The new deal at work. Boston. Mass: Harvard Business School Press.

Davis, S. \& Meyer, C. (1998) Blur. The speed of change in the connected economy. Reading, Mass: Perseus Books.

Groshal, S. \& Bartlett, C.A. (1997) The individualized corporation. New York: Harper Collins.

Hesselbein, F. Goldsmith, M. \& Bechard, R. (Eds) (1997) The organization of the future. San Francisco: Jossey-Bass.

Hock, D. (1999) Birth of the chaordic age. San Francisco: BerrettKoehler.

Howard, A. (Ed) (1995) The changing nature of work. San Francisco: Jossey-Bass.

Kriek, H.J. (1996) Bedryfsielkunde in Suid Afrika: 'n Toekomsperspektief. Tydskrif vir Bedryfsielkunde, 22(1), 7-11.
Stacey, R.D (1996) Complexity and creativity in organizations. San Francisco: Berret-Koehler.

Ulrich, D., Losey, M.R. \& Lake, G. (Eds) (1997) Tomorrow's HR Management. New York: John Wiley.

Veldsman, T.H. (2002) Into the people effectiveness arena. Navigating between chaos and order. Johannesburg: Knowledge Resources.

Wheatley, M.J. (1994) Leadership and the new science. Learning about organization from an orderly universe. San Francisco: Berret-Koehler.

Wind, J.Y. \& Main, J. (1998) Driving change. How the best companies are preparing for the 21st century. London: Kogan Page.

Zohar, D. (1997). Rewiring the corporate brain. Using the new science to rethink how we structure and lead organizations. San Francisco: Berret-Koehler. 